\title{
LEX ORANDI, LEX CREDENDI ET LEX VIVENDI: IBADAH DAN PERILAKU KEHIDUPAN ORANG PERCAYA
}

\author{
Mariani F. Lere Dawa
}

\begin{abstract}
Abstrak: Betapa sering orang percaya menghadiri ibadah minggu demi minggu, namun kehidupan dan perilakunya tidak menunjukan sebagai seorang yang beribadah. Terputusnya relasi di antara ibadah dan kehidupan dalam kebanyakan orang percaya menantang gereja untuk menolong dan melatih umat mengenai apa sebenarnya yang terjadi di dalam ibadah, khususnya ibadah yang ditindaki dengan seperangkat liturgi. Liturgi yang dilakukan oleh gereja sebenarnya bukan sekedar urutan acara yang dilakukan dalam ibadah, melainkan liturgi adalah jendela kehidupan dalam kerajaan Allah, bahwa sedemikianlah seharusnya umat itu hidup sehari-hari. Ibadah dalam ruang yang tersedia dengan perangkat liturgi yang ada menjadi simbol bagaimana umat seharusnya hidup di dalam dunia, karena ruang ibadah itu adalah ruang dunia dan liturgi itu adalah cara kehidupan orang percaya yang diringkas dalam satu pola kehidupan. Dalam hal ini, maka liturgi itu sebenarnya juga menjadi acuan pelatihan dari gereja bagaimana memuridkan umat Allah untuk menjadi umat yang diutus masuk ke dalam dunia dengan membawa kehidupan ilahi, sebagai garam dan terang dunia.
\end{abstract}

Kata-kata Kunci: Ibadah, Liturgi, misi dan perilaku orang percaya

Abstract: Worship is the center of christian life. However, It is often happen that the people of God attend worship service every Sunday, and yet their daily lives are not shaped by what they have done in worship. Sunday worship seems being segregated in christian life. The cause of gap that emerges between worship and daily life is because the church does not know that worship or liturgy in its order indeed is the window of the kingdom. There are lot of church members do not get the meaning at what is in worship and why the church sets the liturgy. In fact, liturgy is the means of discipleship, and therefore, there is a close connection 
between what we are doing in worship/liturgy and in turn, what we are doing in the world.

Worship in its liturgical forms is not something that is meaningless. Every part of the church liturgy has its own meaning. Therefore, it is very significant for the church to teach and train her church members about the meaning of liturgy and why the church acts her worship in that way. From the beginning till the end of the litrugy, all is a whole structural pattern of the expression of how the people of God should live in God's world. Liturgy helps the people of God to lift up his life in the world and how to performs that life, which is in harmony with God's will. The well performance of christian life in the world is a good expression of identity and mission of the church. Therefore, the Latin maxim that addresses the centrality of worship in the life, identity and mission of the Church; "Lex Orandi, Lex Credendi" gets its deepest meaning and implication to strengthen the church and to fulfill God's mission in the world.

Keywords: Worship, Liturgy, mission and christian life

\section{PENDAHULUAN}

Ungkapan bahasa Latin Lex Orandi, Lex Credendi, Lex Vivendi mengisyaratkan sentralitas yang penting dari ibadah dalam kehidupan, identitas dan misi gereja. Implikasi dari ungkapan ini adalah bahwa ibadah itu merefleksikan apa yang dipercayai oleh orang percaya dan ibadah itu juga akan mengarahkan bagaimana orang percaya akan hidup dalam dunia. Dalam hal ini, ibadah adalah sarana dinamis untuk membawa orang percaya mengalami kepenuhan kehidupan Kristus, karena ibadah yang baik menginformasikan dan mentransformasikan pribadi dan komunitas orang percaya, agar orang percaya siap masuk ke dalam dunia, untuk memberitakan karya penebusan Yesus Kristus.

Sebagai akibat dari hal ini, maka pertanyaan penting muncul di sini, yaitu: "Apakah sebenarnya yang terjadi dalam ibadah Minggu orang percaya?" Tentu saja banyak yang beranggapan bahwa ibadah itu adalah 
suatu tempat pelarian dari stress, suatu kesempatan untuk melupakan tragedi, masalah, dan kekecewaan dalam hidup. Karena itu, seringkali jemaat datang ke dalam ibadah dengan cara menanggalkan beban di belakang dan masuk untuk memuji Tuhan karena merasa bahwa paling tidak bahwa ibadah itu memberikan kelepasan sementara dari persoalan hidup.

Yang menyedihkan adalah sikap dan perilaku seperti ini didukung pula oleh para pemimpin ibadah, di mana mereka mengajak umat memuji Tuhan dengan cara mendorong mereka melupakan masalah mereka sejenak, karena mereka sekarang sedang ada di hadapan Tuhan. Sikap seperti ini justru menjebak orang percaya masuk ke dalam suatu sukacita semu, karena apa yang terjadi seperti ini dalam ibadah hari Minggu tanpa disadari justru akan dapat membuktikan tesis dari Karl Marx bahwa agama itu sesungguhnya adalah opium masyarakat; ibadah seolah-olah menjadi obat, yang membuat orang percaya melayang sejenak dan mengalami "religious trance".

Karena itu, apakah yang seharusnya dan yang sepantasnya orang percaya lakukan dalam ibadah setiap Minggu? Dapatkah ibadah Minggu itu dikaitkan dengan suatu anestesi rohani berhadapan dengan pengalaman orang beriman? Atau dapatkah dikatakan bahwa ibadah itu laksana kursi goyang untuk membuat orang percaya hangat, dan merasakan mati rasa dari kepedihan dan kesulitan hidup? Artikel ini akan membahas apa itu sebenarnya ibadah dalam hidup Kristen dan unsurunsur pembentuk dari ibadah itu serta fungsinya dalam hidup Kristen.

\section{APA ITU IBADAH MINGGU?}

Istilah ibadah dalam bahasa Inggris, worship, berasal dari kata worth-ship, yang menegaskan nilai yang ditempatkan pada seseorang atau sesuatu. Jikalau seseorang menghargai sesuatu atau seseorang, maka dia akan melakukan sesuatu untuk mendemonstrasikan rasa cintanya 
tersebut. ${ }^{1}$ Ibadah dalam hal ini adalah suatu tindakan manusia terhadap siapa yang dia kasihi dan hargai dalam hidup. Karena itu, pada dasarnya, ibadah itu secara definitif adalah suatu tindakan pengakuan orang percaya kepada Allah yang memang layak dan patut dipuji, dan karena itu, hanya kepada Dia sajalah segala sesuatu yang termulia dipersembahkan. Hal ini tidak berarti bahwa Allah sedemikian egoisnya menginginkan penyembahan manusia, karena secara hakiki di dalam diri Allah sendiri segala sesuatu sudah terpuaskan dan tidak diperlukan tambahan sesuatu yang lain dari manusia untuk menambah kepuasan dalam eksistensi diriNya. Ibadah dimungkinkan dilakukan oleh orang percaya, karena anugerah perjanjian-Nya kepada manusia melalui Kristus dan melalui Kristus orang percaya datang kepada Allah di dalam ibadah.

Kata ibadah dalam kitab Suci merupakan kata kerja yang menunjuk kepada suatu tindakan (yakni dengan menunduk, berlutut atau mencium tangan seseorang) sebagai ungkapan pengakuan akan pribadi yang lebih mulia dan termulia. Dari Votum hingga Berkat dalam ibadah semuanya merupakan suatu dialog terbuka di antara pelayan dan jemaat, di antara Allah dan umat-Nya. Di dalam ibadah itu nampak suatu inisiatif Allah untuk membuka diri-Nya dalam Kristus melalui Firman dan mengikat orang percaya dalam ikatan perjanjian-Nya. Orang percaya selanjutnya dalam ibadah memberikan respon terhadap kemuliaan Allah yang dinyatakan dalam panggilan ibadah tersebut. Ibadah bersama pada hari Tuhan merupakan suatu sarana sentral yang olehnya juga orang percaya secara bersama-sama saling mendorong dan membangun satu sama lain.

Karena itu, Wolterstorff menggambarkan fungsi dari ibadah Minggu itu seperti jantung yang berdetak secara sistolik-diastolik. ${ }^{2}$ Artinya, kala jantung memompa darah itu sendiri dan mendistribusikan darah dari jantung ke semua bagian tubuh mnanusia dan mengembalikan itu lagi ke jantung, maka jantung itu memompa dengan menarik darah

1 Graham Kendrick, Learning to Worship as a Way of Life, (Minneapolis: Bethany House Pub., 1984), p.23.

2 Nicholas Wolterstorff, Hearing the Call: Liturgy, Justice, Church and World, (Grand Rapids: Eerdmans, 2011), p.19. 
untuk dirinya juga, menggantikan dan memperkuat cairan dengan oksigen yang memberikan kehidupan dan mengirimkan itu ke tubuh dalam getaran irama yang berkelanjutan. Hal ini berarti bahwa ibadah itu justru bukan sebagai suatu tempat untuk melupakan masalah, penderitaan dan kesakitan hidup orang percaya. Sebaliknya, ibadah itu justru menjadi suatu tempat pelatihan di mana orang percaya dapat belajar untuk bersikap benar dengan semua persolan hidupnya. Karena itu, ketika orang percaya datang beribadah menyembah Allah, mereka justru datang dengan membawa seluruh keadaan hidup mereka bersama dengan mereka, sebagaimana Wolterstorff menegaskan,

We leave our homes, our offices, our playgrounds, and assemble for the liturgy. But we do not leave behind our experience in our lives of dispersion. We carry that experience along with us. A fundamental dimension of the liturgy is that in it we give expression, in concentrated and condensed ritualized form, to our experience in the world an our response to that experience. ${ }^{3}$

Pengalaman dalam ibadah yang dimanifestasikan dalam liturgi adalah sebenarnya bentuk kehidupan dan pengalaman orang percaya dalam dunia dan sekaligus juga respon orang percaya terhadap pengalaman demikian. Apa yang terjadi dalam ibadah sebagai suatu bentuk ekspresi yang dipadatkan dalam realitas kehidupan yang akan orang percaya masuki dalam dunia menunjukan bahwa apa yang terjadi dalam ibadah Minggu menjadi kunci penting jemaat memberikan respon terhadap pengalaman kehidupan dalam dunia secara benar. Ada suatu keterkaitan yang sangat erat di sini di antara pengalaman ibadah dan pengalaman kehidupan dalam dunia. Artinya, ibadah dalam tradisi Reformed bukanlah suatu pelarian dari apa yang disebut banyak orang sebagai suatu pelarian dari dunia sekuler menuju kepada suatu dunia sakral.

Perayaan liturgi dalam ibadah Minggu justru merupakan suatu respon orang percaya kepada suatu pemahaman bahwa dunia ini adalah karunia dan karya mulia dari Allah. Karena itu sebagai orang percaya,

3 Wolterstorff, Hearing the Call, p.23. 
kala mereka datang dalam ibadah Minggu, mereka juga membawa pengalaman dalam dunia itu bersama diri mereka dengan tujuan untuk memahami dengan benar realitas dunia itu di mana orang percaya hidup dan berkarya dengan penuh ucapan syukur dan sikap penyembahan kepada Allah. Orang percaya membawa pengalaman mereka bersama dalam ibadah dengan melihat dalam cara yang benar dan menaikkan syukur dan penyembahan mereka dalam kata dan pujian, dalam sikap dan warna, memuji Allah untuk apa yang sudah mereka alami dalam dunia.

Dalam ibadah Minggu, orang percaya membawa ucapan syukur, penyesalan, dan ratapan dari kehidupan mereka bersama dan kala mereka pergi meninggalkan ibadah, mereka membawa dalam hidup mereka petunjuk dan kekuatan, keberanian dan pengharapan, dari apa yang sudah mereka terima dalam ibadah. Karena itu, ibadah Minggu bukanlah untuk membuat orang percaya melupakan tragedi kehidupan, melainkan ibadah Minggu justru untuk membuat mereka mengingat tragedi itu secara benar, yaitu dalam kerangka Kitab Suci dan berjalan dalam dunia dengan penuh keberanian. Itulah sebabnya, dalam liturgi ibadah Mingggu itu menampilkan pujian, ratapan, ucapan syukur, berserah kepada Allah, doa, mendengar firman, sakramen, dan pergi dengan dedikasi dan janji. Di dalam semua kerangka liturgi ini mencakup aspek-aspek permohonan, pujian, disorientasi dan reorientasi. ${ }^{4}$

Ibadah Minggu itu akan menjadi semakin bermakna apabila orang percaya memahami karakteristik sebenarnya yang sedang terjadi dalam ibadah. Ibadah yang dilakukan oleh orang percaya benar-benar menjadi otentik apabila orang percaya mengalami dunia, di mana orang percaya hidup dan berkarya sebagai karunia dan karya mulia Allah dan merasakan sukacita dari ucapan syukur karena orang percaya hadir di dalamnya sebagai mitra kerja Allah. Orang percaya mengalami berbagai macam pengalaman dalam dunia, termasuk di dalamnya pengalaman penderitaan dan kejahatan moral dari dunia karena ketidaktaatannya. Semua peristiwa yang terjadi dapat dilihat bukan dalam keterpisahan dengan Allah karena justru Allah yang sudah mengikat perjanjian dengan umat-Nya melalui

4 John D. Witvliet, Worship Seeking Understanding, (Grand Rapids: Baker Books, 2003), p.56. 
Putra-Nya adalah Dia yang juga sudah menderita di atas penderitaan orang percaya. Dalam hal ini, penderitaan umat Allah di sini dilihat dalam perspektif penderitaan Putra-Nya, laksana darah yang mengalir dari luka di Golgota yang menyembuhkan luka-luka dunia ini. ${ }^{5}$

Akibatnya, untuk mengalami transformasi dalam ibadah gereja diperlukan suatu kesadaran penuh bahwa orang percaya sudah berdosa dalam dunia-Nya dan merasakan penyesalan dan mau bertobat, jika tidak demikian, maka tindakan ibadah orang percaya hanyalah suatu tindakan lahiriah semata. Orang percaya harus sungguh mengalami dunia dalam perspektif penderitaan Sang Putra dan merasakan penderitaan dari teriakan ratapan orang yang menderita, karena jika tidak, maka kata-kata syafaat orang percaya adalah kata-kata semata. Wolterstorff selanjutnya menegaskan, "authentic experience and life in the world is a condition of authentic liturgy. If the condition is not satisfied. God finds our words, songs, and gestures deficient, sometimes even nauseous. ",6

\section{PRINSIP DAN MOTIF MEMBANGUN IBADAH MINGGU}

Secara jelas, Gereja tidak dapat memisahkan pemahaman teologi dari liturgi atau tindakan dari beribadah. Kedua hal ini saling berkaitan, karena teologi menginformasikan liturgi dan liturgi menginformasikan teologi. Ada 4 prinsip yang perlu diperhatikan di sini dalam membangun ibadah orang percaya, yaitu: Pertama, bentuk dari liturgi harus selaras dengan Regulative Principle dari Kitab Suci. Artinya elemen-elemen ibadah dalam Kitab Suci nyata dalam liturgi.

Chapell menyebutkan bahwa bentuk dari liturgi gereja justru menceritakan pemahaman akan kisah Injil. Artinya di dalam ibadah itu ada kebenaran-kebenaran hakiki dalam Injil tentang penebusan Kristus yang tetap tidak berubah, dan di dalam ibadah gereja menyampaikan

\footnotetext{
5 Wolterstorff melihat dimensi unik dari ibadah ini dengan berhutang kepada pemikiran dari Jürgen Moltmann. Untuk memahami sisi unik ini dapat dilihat dalam Jürgen Moltmann, The Crucified God: The Cross of Christ as the Foundation and Critisism of Christian Theology, (Minneapolis: Fortress Press, 1993), p.27-274.

6 Wolterstorff, Hearing the Call, p.28.
} 
kisah ini dengan konsisten. Jikalau penyampaian ini konsisten, maka ada aspek ibadah yang tetap harus konsisten dan harus ada dalam ibadah. ${ }^{7}$ Calvin menyebutkan contoh bagian elemen ini ${ }^{8}$ dan juga susunan liturginya, yaitu Firman Tuhan dibaca, pengakuan dosa, Firman Tuhan diberitakan, sakramen dijalankan, doa, pujian dan persembahan diberikan, dorongan untuk hidup dalam kekudusan dan berkat diberikan sebelum jemaat meninggalkan tempat mereka. ${ }^{9}$ Meskipun dalam tradisi beberapa tokoh gereja berbeda dalam penyusunan urutan dalam liturginya, namun ada unsur yang sama yang selalu muncul dalam liturgi, yang justru menyampaikan kisah tentang bagaimana Allah menggunakan liturgi untuk memberitakan Injil-Nya dan mendidik umat-Nya dalam kebenaran. Chapell memberikan beberapa contoh unsur dalam urutan yang berbeda ini dari tradisi Roma pra 1570, dari Martin Luther (ca 1526), dari Calvin (ca 1542), dari Westminster (ca 1645) dan dari tradisi modern dari Rayburn (ca 1980). ${ }^{10}$ Di samping unsur-unsur regulatif itu, ibadah jemaat juga bersifat sederhana, dengan tidak mengurangi makna adanya berbagai macam pernak-pernik dalam ibadah apakah itu vokal group, paduan suara, simbol-simbol dan sebagainya; artinya segala ibadah diarahkan bagi pemberian kemuliaan bagi Allah.

Kedua, bentuk/susunan dari liturgi adalah covenantal order. Urutan ini menegaskan bahwa ibadah itu sangat kental dengan ide perjanjian, di mana Allah sebagai inisiator dalam ibadah dan manusia sebagai responden dari kasih karunia Allah. Karena itu, berkenaan dengan ini maka dalam susunan liturgi nampak elemen dari sisi Allah dan elemen dari sisi manusia. Ketiga, Kebersamaan (persekutuan orang kudus dalam satu kesatuan ibadah bersama). Kebersamaan ini memberikan penekanan bahwa ibadah yang dilakukan bukanlah aksi individu semata namun aksi ini ada dalam konteks kebersamaan dengan jemaat yang lain (sense of corporateness); meskipun hal ini tidak berarti individu itu terbenam dalam lautan kebersamaan; kunci pikiran dari

\footnotetext{
7 Bryan Chapell, Christ Centered Worship: Kiranya Injil Membentuk Perbuatan Kita, (Malang: Literatur SAAT, 2009), p.95.

8 John Calvin, Institutes IV.xvii.44 dan susunan liturgi dalam Institutes. III.iv.10f

9 Lihat penjelasan ini juga dalam ulasan Bard Thompson dalam Liturgies of the Western Church, (Philadelphia: Fortress Press, 1961), p.185-186.

10 Chapell, Christ Centered Worship, p.96-97.
} 
Reformed dalam sistem teologianya adalah sistem berimbang ( $a$ balanced system), yaitu di antara dirinya sebagai individu dan kebersamaan orang percaya dalam beribadah.

Karena public worship adalah ibadah bersama dan bukan private worship, maka dalam perspektif adorasi, perlu diingat mengenai integritas dari persekutuan dengan Kristus dan sesama dalam ketaatan dan kekudusan. Menurut Calvin, gereja adalah persekutuan dari umat yang dipilih, umat Allah yang kudus. Karena itu, liturgi dibuat bukan untuk menghibur hati individu-individu semata; liturgi adalah instrumen bersama dari umat pilihan Allah, yang telah menerima firman Allah dan memberikan pujian yang sepantasnya kepada Allah. Karena itu liturgi adalah suatu tindakan ekspresi bersama dari umat Allah setempat terhadap karya penebusan Allah. ${ }^{11}$

Keempat, Menyembah dalam Roh (bandingkan Yohanes 4:24). Kedinamikaan dari ibadah terletak pada kesatuan dari orang percaya yang beribadah melalui kuasa Roh Kudus yang membawa aplikasi penebusan Kristus bagi orang percaya. Artinya jangan sampai orang percaya terjebak dalam setting liturgical forms yang mengabaikan ekspresi dalam beribadah dan sebaliknya jangan sampai terjebak pada ekspresi yang melampaui keteraturan dalam beribadah. Dalam ibadah, umat memberikan respon terhadap gerakan Roh Allah dalam hati orang percaya, dan Roh yang mengarahkan itu adalah Roh Kebenaran, yang kekal dan Ia tidak akan bekerja bertentangan dengan diri-Nya sendiri dalam menuntun umat-Nya. Karena itu ibadah macam ini dikristalisasikan dalam liturgi klasik $^{12}$ dari gereja, dan dibentuk berdasarkan kerangka historis penyataan Allah dalam Firman dan dilaksanakan dalam tradisi gereja bahwa orang percaya beribadah karena

\footnotetext{
Band. Bard Thompson, Liturgies of the Western Church, p.194.

Liturgi klasik yang mencakup elemen-elemen klasik standar tertentu dikembangkan sejak abad ke 2 dari gereja mula-mula, khususnya dalam liturgi dari Justinus Martir (c.a 150 ). Meskipun demikian beberapa elemen walaupun belum tersusun dengan khusus dalam liturgi standar sudah tercatat dalam Didache (ca. 50-150). Lihat keterangan dan diskusi lebih lanjut dalam Ralph P. Martin, Worship in the Early Church, (Grand Rapids, Mi: Eerdmans, 1964), p.130-140.
} 
digerakkan oleh Roh Allah yang secara konsisten bekerja dari masa lalu dan dalam kekinian hari ini. ${ }^{13}$

Dalam penyembahan kepada Allah, orang percaya sadar bahwa mereka sedang memasuki hadirat-Nya, menikmati persekutuan dengan Dia, dan menyembah Dia dengan hati, pikiran, kehendak dan emosi. Bahaya besar hari ini adalah apabila orang percaya membuat ibadah mereka hanya sekedar penampilan luar dan formal, sementara ibadah dalam roh, bukan sekedar tampilan luar yang berkaitan dengan semua perubahan dalam liturgi yang membangkitkan daya tarik, dan juga sekedar penyembuh bagi formalisme dalam ibadah. Umat datang bukan sebagai penonton melainkan sebagai partisipan dalam ibadah. Di samping itu penyembahan itu adalah mengenal kebenaran Allah dan pengakuan akan kebenaran Allah dalam Firman-Nya. Allah adalah Roh dan menyembah Dia dalam roh dan kebenaran memberikan implikasi bahwa doktrin ibadah itu merupakan perwujudan dari doktrin orang percaya tentang Allah.

Ibadah itu menyangkut komunikasi, baik itu komunikasi verbal maupun komunikasi non verbal. Ekspresi liturgi di dalam aspek komunikasi non verbal dapat memperkaya ibadah jemaat, apabila ekspresi itu berjalan beriringan dengan Kitab Suci. ${ }^{14}$ Beberapa pertanyaan di bawah ini dapat menolong orang percaya memahami ekspresi liturgi dalam komunikasi non verbal untuk memperkaya kehidupan ibadah.

Pertama, apakah gaya dalam berekspresi yang nampak dalam berbagai macam kultur hari ini memiliki signifikansi yang sama dalam ekpresi? Jika jawabannya ya, maka ekspresi itu dapat ditransferkan ke dalam ibadah secara bersama, misalnya, berdiri itu sebagai tanda penghormatan, berdoa dengan mengangkat tangan, di mana dalam gerakan Pentakosta, ekspresi ini dipakai sebagai gaya yang umum untuk semua jemaat; mata yang menengadah ke atas, menaruh tangan di dada,

13 Raymond Abba, Principles of Christian Worship, (London: Oxford University Press, 1957), p.9.

14 Diskusi panjang tentang ekspresi tubuh dalam ibadah dibahas dengan baik oleh Craig Douglas Erickson, Participating in Worship: History, Theory, and Practice (Louisville: Westminster/John Knox Press, 1989), p.149-179. 
pemakaian yang umum bagi orang Yahudi, dan Agustinus mencatat penggunaan cara ini dalam liturgi gereja mula-mula, Confiteor, tindakan pembuka dari pengakuan dosa yang berarti ekspresi kesadaran akan dosadosa yang telah diperbuat; tepuk tangan yang menandakan suatu letupan sukacita dan ekspresi-ekspresi lainnya.

Kedua, apakah gaya dalam berekspresi itu sudah dipakai dalam gereja Reformed dan apakah hal itu juga dipakai dalam praktek gereja mula-mula (jikalau orang percaya konsisten melihat prinsip normatif tradisi kembali kepada Kitab Suci dan praktek gereja mula-mula sebagai ujian aplikasi dari Kitab Suci). Hal penting yang dapat direnungkan adalah, "Apakah gereja hari ini sedang mempraktekkan budaya Victorian Kontinental pada Abad Pertengahan di masa lalu?, dan bagaimana dengan ekspresi ibadah dalam kekinian hari ini? Ketiga, kebersamaan dalam melakukan. Artinya di sini jangan hanya sekedar memberikan reaksi yang berlebihan kepada apa yang Kharismatik atau apa yang gereja Katholik lakukan, namun pertanyaan dasarnya adalah apa yang dapat orang percaya lakukan untuk menyembah Allah secara benar sebagai umat-Nya pada hari ini?

Selanjutnya, pertanyaan-pertanyaan penuntun yang digagas oleh Riemer akan dapat sangat menolong gereja untuk melakukan perubahan atau mempertahankan liturgi. Menurut Riemer, hakekat dalam mempertahankan dan mengubah/mengembangkan liturgi sebaiknya dipahami sedemikian rupa, sehingga usaha ini justru akan dapat membawa kebangunan dalam kehidupan jemaat. Riemer menyatakan bahwa,

...dalam proses sekularisasi orang percaya didorong untuk menafsirkan, mengerti, dan menyifatkan niat mengubah atau mempertahankan liturgi di lingkungan orang percaya sendiri, di gereja mereka sendiri. Apa motivasinya untuk bertindak terhadap liturgi? Apa latar belakangnya yang sebenarnya? Bukan tidak mungkin gereja mereka sendiri juga ditimpa bahaya ajaran palsu, kelemahan iman sejati atau sekularisasi! Bisa saja tindakan- 
tindakan terhadap liturgi (baik niat mengubah atau niat bertahan) hanyalah simptom berbagai kelemahan mendasar! $!^{15}$

Berkaitan dengan hal di atas, maka segala sesuatu dalam ibadah harus dapat membawa kebaikan dan dapat membangun kehidupan jemaat bersama-sama. Adalah sangat bertentangan dengan prinsip reformasi jikalau orang percaya memaksakan liturgi dan gaya dalam berekspresi itu kepada jemaat di mana mereka belum mendapat pemahaman dan pengertian akan hal itu.

Karena itu, guna memperkaya pemahaman jemaat lebih lanjut mengenai makna dari ibadah, Rice juga mengemukakan ada tiga hal penting yang harus diperhatikan, dan hal-hal tersebut adalah festival, misteri dan rasionalitas/emosi. ${ }^{16}$ Pertama, ibadah itu bersifat festival berarti bahwa ibadah itu mencakup suatu rasa penghormatan umat kepada Allah. Tidak bisa tidak, ibadah itu adalah ungkapan hormat orang percaya kepada Allah. Dalam hal ini, ada beberapa pertanyaan pengarah yang akan menolong para pelayan, yaitu "Apakah penghormatan itu hanya dapat berbentuk dalam diam saja?" "Adakah aspek lain dari sisi menghormati?" "Dapatkah menghormati itu dikaitkan dengan memuji dengan bersukacita, bertepuk tangan atau dengan menggunakan bahasa simbol warna, tarian dan pujian?" "Bagaimanakah penggunaan eskpresi yang tepat pada hari ini untuk mengungkapkan penghormatan terhadap yang dihormati?"

Kedua, ibadah itu adalah suatu misteri. Artinya, ibadah itu seharusnya memberikan kepada orang percaya rasa yang menyeluruh akan totalitas keberadaan mereka dan membawa indera mereka secara menyeluruh untuk diliputi oleh Dia yang Mahakudus itu. Dalam kaitan dengan hal ini, maka ibadah itu akan menolong orang percaya mengalami yang Mahakudus sehingga orang percaya ditransformasikan oleh pengalaman keagungan itu, di mana sisi misteri dari ibadah menembus diri orang percaya. Kemisterian ini nampak dalam susunan dan pola

\footnotetext{
15 G. Riemer, Cermin Injil: Ilmu Liturgika, (Jakarta: Yayasan Komunikasi Bina Kasih/OMF, 1995), h.204.

16 Howard L. Rice \& James C. Huffstutler, Reformed Worship, (Louisville, Ky: Geneva Press, 2001), p.195-196.
} 
liturgi untuk memberikan pengajaran dasar tentang Allah dan karya penebusanNya bagi diri orang percaya secara individu dan juga secara bersama sebagai umat kudus yang bersekutu.

Ketiga, ibadah itu juga menyangkut dimensi rasionalitas di samping emosi. Artinya, tanpa pemahaman secara rasional maka ibadah hanya sekedar masalah emosi yang hanya terbatas pada ruang ibadah namun tidak dapat diterjemahkan dalam hidup sehari-hari. Rice mengamati bahwa tiga cabang besar dalam sejarah kekristenan kerap kali menekankan satu dimensi dari gambaran ibadah yang menyeluruh ini: Kristen Orthodoks menekankan dimensi festival, Roma Katholik menekankan aspek mistik dan Gereja Protestan menekankan aspek rasionalitas. Bahkan dalam cabang Protestan pun terbagi menjadi beberapa bagian: Pentakosta menekankan festival, Anglikan menekankan misteri dan Reformed menekankan rasionalitas (cerebral domain). Jikalau gereja serius hendak melakukan suatu perubahan dalam liturginya, maka sebaiknya gereja memperhatikan ketiga hal di atas. ${ }^{17}$

Ibadah yang inspiratif itu juga mencakup empat motif yang mendasari usaha orang percaya dalam membangun ibadah Minggu: Empat motif tersebut adalah: ${ }^{18}$ Pertama, motif Kitab Suci: Meskipun Kitab Suci tidak memberikan suatu susunan ibadah, Kitab Suci tetaplah sebagai orientasi dasar yang tidak dapat ditawar-tawar otoritasnya dalam ibadah, karena Kitab Suci menyatakan mengenai Allah yang orang percaya sembah. Kedua, motif katholik (sejarah dari gereja): Gereja yang beribadah ini secara organis diikat dalam gereja yang kelihatan dan tidak kelihatan. Sejarah gereja memberikan orang percaya suatu rasa apresiasi terhadap apa yang seharusnya menjadi prinsip (regulative principle) dalam ibadah dan apa yang menjadi fleksibilitas dalam ibadah.

Ketiga, motif Pengakuan iman gereja, di mana setiap gereja yang berkumpul untuk beribadah mengakui doktrin-doktrin tertentu yang diartikulasikan dalam cara-cara tertentu (lex credendi lex orandi).

17 Rice, Reformed Worship, p.196.

18 Worship Study Committee, Authentic Worship in A Changing Culture, (Grand Rapids, MI: CRC Publications), p.6-8. 
Meskipun kredo formal dan pengakuan doktrinal tidak terungkap secara eksplisit dalam ibadah, apa yang gereja percayai dan bagaimana gereja beribadah seharusnya diintegrasikan sebagai ekspresi dari doktrin kepercayaannya. Keempat adalah motif pastoral (kebutuhan kontemporer dari umat Allah): Jemaat yang beribadah adalah jemaat yang khusus di sini dan sekarang. Motif ini memanggil para pemimpin ibadah untuk bertanya siapakah umat yang beribadah hari ini, kebutuhan mereka, apakah yang sedang menjadi kompetitor dalam ibadah mereka dan bagaimana mereka mendengar?

Apa yang sedang bergerak dalam ibadah hari ini khususnya sejak munculnya kebangkitan dari ibadah kreatif dalam era 1960-an mendorong tim ibadah hari ini kembali melihat pergerakan ibadah yang sangat drastis hari ini. Sejak tahun 1968 ada empat katalisator perubahan dalam ibadah Protestan yang hari ini sedang mewarnai juga dunia ibadah Protestan khususnya denominasi Reformed di Indonesia. Adapun katalisator perubahan tersebut, Pertama yang disebut sebagai gerakan liturgi oikumenis. Gerakan ini sudah terjadi secara mendunia, di mana gerakan ini memengaruhi ibadah Protestan untuk melakukan pembaharuan dalam konteks ibadah yang didasarkan pada ibadah gereja mula-mula (abad 2-4 M).

Gerakan liturgi modern ini yang dimulai pada abad ke 18 dan 19 menantang gereja dalam pembaruan liturgi dan masuk ke dalam konsepsi baru-meskipun bukan baru dalam arti per se karena hal ini justru merupakan penemuan kembali apa yang tersimpan erat dalam bejana tradisi gereja yang panjang. Meminjam istilah simbolis dari Humanisme Rennaissance, maka gerakan ini dapat dikatakan sebagai suatu "ad fontes argumentorum" dalam ibadah, karena gereja menemukan kembali kekayaan dari liturgi gereja dengan penekanannya pada sisi sakramental, namun cakupannya bersifat oikumenis. ${ }^{19}$

Bahkan Gereja Katholik yang bertahan panjang dalam menara tradisi dan yang telah berupaya untuk mempertahankan tradisi panjang

19 Raymond Abba, Principles of Christian Worship, (London: Oxford University Press, 1957), p. 40-44. 
gereja juga memberikan sikap terhadap gerakan liturgi oikumenis ini Dalam dokumen konsili Vatican II, Sacrosanctum Concilium, tentang liturgi yang sakral dikatakan demikian:

The sacred council has set out to impart an ever increasing vigor to the Christian lives of the faithful; to adapt more closely to the needs of our age those institutions which are subject to change; to encourage whatever can promote the union of all who believe in Christ; to strengthen whatever serves to call all of humanity into the church's fold. Accordingly it sees particularly cogent reasons for undertaking the reform and promotion of the liturgy.... That is why the sacred council judges that the following principles concerning the renewal and advancement of the liturgy should be called to mind, and that practical norms should be established. Among these principles and norms there are some which can and should be applied both to the Roman rite and also to all the other rites. The practical norms which follow, however, should be taken as applying only to the Roman rite, except for those which of their nature affect other rites as well...In faithful obedience to tradition, the sacred council declares that the church holds all lawfully recognized rites to be of equal legal force and dignity; that it wishes to preserve them in the future and to foster them in every way. The council also desires that, where necessary, the rites be revised carefully in the sight of sound tradition, and that they be given new vigor to meet present-day circumstances and needs. ${ }^{20}$

Dokumen di atas mencantumkan sikap gereja Katholik terhadap gerakan oikumenis, di mana Gereja mengambil sikap pembaharuan diri demi memenuhi kebutuhan umat di tengah jaman hari ini, tanpa harus memperkosa prinsip-prinsip tradisi yang gereja pegang dalam kurun waktu yang panjang.

Kedua, gerakan liturgi modern memberikan perhatian juga kepada penggunaan tahun gereja dalam ibadah. Kalender gereja ini menjadi peringatan tahunan terhadap peristiwa sejarah penyelamatan Allah.

20 Austin Flannery, OP, Gen Ed., The Basic Sixteen Documents Vatican Council II:

Constitutions, Decrees, Declarations, Revised Edition (Northport, New York:

Costello Publishing Company and Dublin, Ireland: Dominican Publications, 1996), p.117-118. 
Berkaitan dengan hal ini juga gereja mengembangkan suatu Revised Common Lectionary sebagai cara mempromosikan membaca Kitab Suci dalam ibadah dan dalam mengkhotbahkan seluruh kitab dalam Kitab Suci." Dalam khotbah ini juga sangat ditekankan khotbah yang bersifat ekspositori, di mana kedua bagian ini bukanlah hal yang asing dalam tradisi Reformed dan kebanyakan gereja dalam denominasi Reformed telah melakukan hal ini. ${ }^{21}$ Doa ucapan syukur dari gereja mula-mula akhirnya menjadi bagian juga dalam liturgi perjamuan kudus. Reformasi dalam liturgi ini sudah diadopsi secara meluas dalam gereja Protestan maupun Katholik dan gereja-gereja satu dengan yang lain dalam tingkatan yang beraneka ragam dengan cara saling meminjam teks liturgi, himne dan pola liturgi.

Ketiga, Gerakan Kharismatik juga turut memengaruhi ibadah Minggu dalam semua tradisi hari ini. Seperti dalam gerakan liturgi, gerakan Kharismatik menekankan pada partisipasi aktif dari jemaat dalam ibadah dengan menggunakan anggota tubuh secara fisik. Secara khusus, gerakan ini sangat menekankan pujian dan doa, ibadah kesembuhan, saat berkumpul bersama para pelayan dalam kelompok kecil untuk berdoa dan bahasa lidah. Gerakan dalam pujian ini ditandai dengan penggunaan beberapa lagu Kitab Suci yang sederhana atau memuji refrein dari pujian, suatu bagian dari tindakan yang menuntun jemaat dalam tindakan dan penggunaan tim dalam memimpin ibadah.

Keempat, Evangelisme garis depan di mana Ibadah jemaat dianggap sebagai kendaraan utama dalam penginjilan dan sasarannya adalah mereka yang non Kristen. Gerakan ini menggunakan analisa sosiologis untuk mengidentifikasikan bentuk khusus dalam budaya yang sedang berkembang, sehingga melahirkan istilah "seeker-sensitive worship, boomer worship, buster worship dan lain-lain menjadi acuan dalam analisa.

21 Meskipun demikian hal ini perlu diperhatikan karena tokoh Reformed pada mulanya-Zwingli dan Farel - telah menghapus lectionary ala gereja Katholik Abad Pertengahan yang hanya mengambil satu teks yang keluar dari konteks. Bagi Calvin, membaca teks demikian - Calvin sangat menekankan berkhotbah secara berurutan untuk semua teks Kitab Suci-tidak akan bisa mendidik jemaat dalam pemahaman Kitab Suci yang benar. 
Ibadah Kristen juga dipengaruhi oleh keanekaragaman budaya pada hari ini. Para sejarawan menyebutkan era ini sebagai suatu era eclecticis, Webber menyebut ini sebagai era convergence, dan White menyebut ibadah Protestan dan Katholik pada hari ini bersifat convergence. ${ }^{22}$ White juga memberikan sub judul bukunya yang lain tentang ibadah Protestan hari ini sebagai tradisi dalam transisi. Sub judul ini mengingatkan bahwa gereja ada di dalam persimpangan jalan, ${ }^{23}$ karena adanya upaya pendekatan baru terhadap keaneragaman yang berkembang pada hari ini. ${ }^{24}$

Dalam 30 tahun yang telah lewat, Christian Reformed Church in North America (CRCNA) telah melakukan perubahan khusus dalam ibadah yakni keterlibatan yang bertambah dari kaum awam dalam perencanaan dan memimpin ibadah, adaptasi yang meningkat atau bahkan ada yang meninggalkan bentuk-bentuk liturgi yang telah disetujui oleh Sinode dan juga keanekaragaman yang bertumbuh dalam gaya musik. Di sisi lain, keanekaragaman budaya dan etnis dalam gereja juga memberikan pengaruh adanya keanekaragaman dalam liturgi Katholik Roma dan Orthodoks Timur. Bagi dua kelompok ini, keberagaman merupakan bagian dari ekspresi-ekspresi dan bentuk-bentuk pemikiran yang lebih alamiah dalam gereja. ${ }^{25}$

Studi yang dilakukan CRCNA juga menjabarkan secara khusus tantangan yang sedang dihadapi dalam budaya modern. Meskipun hasil studi ini merupakan suatu riset terhadap apa yang terjadi dalam kebudayaan Amerika, namun secara umum dapat dikatakan bahwa perubahan fenomena budaya yang terjadi saat itu justru sedang melanda dunia termasuk juga Indonesia. Dalam gambaran yang diberikan ternyata gereja hari ini hidup dalam budaya transisi di mana masyarakat hidup dalam budaya konsumeristik, mobilitas yang tinggi, perkembangan teknologi visualisasi yang luar biasa dan kebutuhan akan rasa di mana

\footnotetext{
22 White, Protestant Worship: Traditions in Transition, (Louisville, Ky: Westminster John Knox Press), p.212.

24 Ibid.

25 James F. White, Pengantar Ibadah Kristen, (Jakarta: BPK Gunung Mulia, 1980), h.19-27.
} 
orang tidak lagi ingin melihat ibadah itu dalam istilah "kata" dan mendengar kata-kata melainkan mereka ingin juga mengalami Firman itu (not only about hearing but also experiencing the Word), karena dunia pada hari ini juga ditandai dengan berbagai macam kompleksitas masalah pastoral. Meskipun hal ini dapat menjadi bagian penting namun hal ini tidaklah menjadi determinator akhir dalam ibadah Kristen hari ini.

Memperhatikan katalisator perubahan dalam liturgi Protestan di atas dengan berbagai macam paradigma yang memengaruhi gereja, maka ada hal penting yang dapat diperhatikan di sini, sebagaimana Chapell mengingatkan,

Melihat bagaimana Injil mengendalikan bentuk-bentuk yang mengkomunikasikan Injil bukan hanya menjaga kesinambungan ibadah gereja selama berabad-abad menjadi luar biasa; pemahaman seperti ini juga memaksa kita bertanya apakah bentuk-bentuk ibadah kita benar-benar mencerminkan kisah Injil pada zaman kita. Ibadah bukanlah sekedar masalah pilihan yang dibuat secara asal-asalan, tradisi gereja, preferensi pribadi, atau daya pikat budaya....kita harus memperhatikan cara Allah mempertahankan berita yang terus bergema di gereja-Nya selama berabad-abad. ${ }^{26}$

Kutipan ini menegaskan bahwa aspek masa lalu, dan kini memang tidak dapat diabaikan, namun yang terpenting adalah bahwa gereja memperhatikan apakah liturginya itu sedang bercerita tentang karya Allah dalam Kristus, yang pada gilirannya nanti mendidik orang percaya dalam kehidupan iman mereka sehari-hari sebagai murid Yesus Kristus.

\section{UNSUR DAN FUNGSI LITURGI DALAM IBADAH MINGGU}

Seringkali disebutkan bahwa bagaimana orang percaya beribadah itu sangat berpengaruh dengan kehidupan rohani orang percaya seharihari. Karena, "the how of worship is vital to our growth in grace and in the knowledge of the one true God". Dalam hal ini ibadah membentuk

26 Chapell, Christ Centered Worship, p.95. 
perilaku hidup orang percaya sehari-hari, "we become like what we worship" dan juga "we become like how we worship", seperti yang sangat ditekankan dalam teologi Reformed. ${ }^{27}$ Ibadah dan tindakan liturgi yang dilakukan itu tidak berhenti pada ruangan gereja namun diteruskan dalam ruang kehidupan, membentuk perilaku kristiani. Adalah suatu tragedi besar dalam liturgi Protestantisme, demikian Wolterstorff meratapi, bahwa ibadah itu tidak membentuk perilaku hidup orang percaya sehari-sehari,

If the worship is performed but the works of mercy and justice are missing, a shadow is cast over the worship and its authenticity is brought into question. For this very same God whom we are to worship by celebrating God's deeds in memorial also requires of us that, in grateful response to those deeds, we take heed of God by doing the works of mercy and justice. ${ }^{28}$

Demikian juga Wolterstorff berargumentasi secara berbalikan berkaitan dengan relasi di antara karya dan ibadah bahwa otentisitas dari karya orang percaya juga diragukan karena tidak dirayakan dalam kenangan akan karya Allah yang luar biasa dalam hidup orang percaya. Jadi, ada suatu korelasi yang sangat kuat dengan tindakan orang percaya dalam ibadah dan sikap perilakunya sehari-hari dalam kerja dan karya. Sebagaimana disebutkan bahwa ibadah itu menuntun kepada etika, yang dalam hal ini ethos dari kehidupan. ${ }^{29}$

Karena itu, sangat penting diperhatikan di sini apa arti liturgi dalam hidup orang percaya kala mereka beribadah kepada Allah. Kata liturgi pada mulanya dipakai dalam percakapan publik karena berkaitan dengan pekerjaan yang dilakukan dengan pembayaran. Liturgi yang dikaitkan dalam ibadah kristiani secara sederhana adalah bentuk dan isi dari ibadah korporat orang percaya. Bentuk dan isi dari liturgi ini menjadi semacam sekolah iman bagi orang percaya di mana di dalamnya

27 Philip Graham Ryken, Derek W.H Thomas and J Ligon Duncan III, ed., Give Praise to God: A Vision for Reforming Worship, (Phillipsburg: P \& R Pub, 2003), p.52-53.

28 Wolterstorff, Hearing the Call, p.35.

29 Charles P. Price and Louis Weil, Liturgy for Living, (New York: The Seabury Press, 1979), p.20. 
liturgi sebagai sarana mengajar cara berpikir kristiani dan juga sikap kristiani. Dalam liturgi gereja ada suatu petunjuk untuk orientasi hidup kristiani dan untuk menguasai kehidupan setiap hari. ${ }^{30}$ Memang pada dasarnya, liturgi tidak melakukan dari dirinya sendiri. Liturgi bukanlah suatu sulapan untuk mengubah hidup orang percaya, melainkan karena Allah Roh Kudus bekerja melalui liturgi untuk menjadikan nyata dan dapat terakses bagi orang percaya apa yang Allah kehendaki bagi orang percaya. $^{31}$

Secara umum, setiap tradisi memulai ibadah dengan pengakuan akan kebesaran dan kebaikan Allah. Dalam liturgi Protestan, ibadah diawali dengan votum dan salam. Votum itu berasal dari kata bahasa Latin yang berarti suatu keinginan. Votum ini lazimnya diucapkan dalam ibadah untuk menegaskan pengakuan orang percaya tentang siapa Allah dan siapa manusia. Pada Abad Pertengahan, votum merupakan suatu ungkapan keinginan dari orang awam untuk melayani Tuhan dengan intensitas yang sama dengan mereka yang masuk dalam biara (hari ini dapat dikatakan sebagai aktivis gereja).

Dalam konteks ibadah, votum dipakai sebagai kalimat pembuka untuk menegaskan suatu ekspresi keinginan bahwa seluruh hidup orang percaya yang dipersembahkan dalam ibadah adalah suatu kehidupan yang dihidupi dengan pengakuan akan pertolongan Allah, dan hanya oleh pertolongan-Nya yang nyata di bumi seperti di Surga, ibadah dan kehidupan itu dimungkinkan diadakan. Abineno menjelaskan bahwa votum itu diucapkan pada awal ibadah untuk "mengkonstatir hadirnya Tuhan Allah ditengah-tengah umat-Nya." Mengutip Van der Leew, Abineno mengatakan bahwa dalam "votum itu terletak amanat, kuasa (eksousia) Allah". ${ }^{32}$ Umat memberikan respons terhadap proklamasi votum ini dengan suatu kata yang menegaskan keyakinan mereka dengan mengucapkan kata amin. Kata amin mengungkapkan keyakinan mereka

\footnotetext{
30 J.A Jungmann, SJ, Pastoral Liturgy, (New York: Herder and Herder, 1962), p.334.

31 Price, Liturgy for Living, p.54.

32 J.L. Ch. Abineno, Unsur-Unsur Liturgia yang Dipakai oleh Gereja-gereja di Indonesia, (Jakarta: BPK Gunung Mulia, 2005), h.4-5.
} 
bahwa memanglah demikian yang terjadi dalam kehidupan, bahwa Allah adalah satu-satunya sumber pertolongan dalam hidup.

Sebagai pembanding dari votum dalam tradisi Protestan, liturgi gereja Orthodox memulainya dengan doksologi, "Terpujilah kerajaan Bapa, Putra dan Roh Kudus sekarang dan selamanya." Permulaan ibadah dengan doksologi ini, mengingatkan umat bahwa dalam kehidupan mereka, perjalanan mereka menuju kepada kerajaan Allah. Karena itu, gereja dalam berkumpul menyatakan tujuan, keinginan, dan daya tarik dari seluruh hidup mereka dalam kehidupan adalah kerajaan Allah. Penerimaan umat dijawab dengan kata amin, sebagai suatu respons persetujuan dari umat untuk mengikuti Kristus dalam kenaikan-Nya kepada Bapa, dan menjadikan kenaikan-Nya ke Sorga sebagai suatu tujuan dari kehidupan umat Allah. Hanya di dalam Kristus-lah, umat dapat berkata amin dan di atas kata ini juga keadaan dari umat manusia ditentukan. Kata amin menyatakan bahwa gerakan menuju Allah sudah dimulai. $^{33}$

Masing-masing tradisi di atas memberikan pengajaran berharga dalam permulaan ibadah bahwa kehidupan itu dimulai dalam Allah dan berujung kepada Allah. Permulaan alur liturgi ini mengajarkan arti penting dalam kehidupan orang percaya dalam berkaya dan bekerja dalam dunia bahwa pertolongan mereka adalah satu-satunya di dalam Allah dan dari tradisi Orthodox jemaat belajar bahwa tujuan dan sasaran hidup ini satu-satunya adalah kerajaan Allah. Kedua hal ini seharusnya membentuk perilaku umat yang beribadah.

Salam adalah ungkapan yang mengingatkan orang percaya bahwa Kristus ada di tengah-tengah mereka, dan Dia membawa damai, kemurahan dan anugerah kepada umat-Nya. Biasanya salam ini diambil dari surat-surat Paulus dan salam ini mengungkapkan kepada penyembah pemberian Allah yang besar tentang anugerah, kemurahan dan damai sejahtera yang telah dibayar lunas melalui darah Yesus Kristus. Salam ini bukan hanya sekedar ucapan selamat pagi atau sore melainkan suatu

33 Alexander Schmemann, For the Life of the World, (New York: Athens Printing Company, 1973), p.29. 
ungkapan salam kepada jemaat atas nama Kristus. Bentuk salam yang sederhana dari gereja perdana adalah "Tuhan menyertai kamu," dan kemudian dijawab oleh jemaat dengan kalimat, "dan menyertai rohmu."

Dalam tradisi Protestan, setelah salam tersebut maka Introitus dibacakan atau dapat juga dinyanyikan oleh paduan suara, khususnya yang berasal dari Mazmur. Berbeda dengan tradisi Roma Kuno, Introitus merupakan nyanyian pengantar yang menghantar Paus dan para Klerus masuk ke ruang ibadah. Introitus/ayat pembuka bertujuan untuk memberikan arahan kepada umat mengenai ibadah, dan ayat ini secara umum dapat diambil dari semua bagian Kitab Suci, dan seringkali juga diambil dari Mazmur. Ayat ini mengajak jemaat untuk beribadah dalam cara yang aktif, dan Kebenaran Kitab Suci tentang ibadah yang dibaca dapat dilakukan dengan mengajak jemaat untuk membaca Kitab Suci secara bertanggapan. Cara ini sama seperti yang biasa dilakukan oleh orang Israel dalam pembacaan Mazmur atau menyanyikannya. Van der Leew, sebagaimana dikutip Abineno, menyimpulkan ketiga bagian pembuka ibadah ini dengan mengatakan bahwa,

Votum memberikan amanat secara am. Salam mengkonstitusikan persekutuan. Kini Introitus menempatkan kebaktian jemaat dalam suasana dari bagian sejarah selamat, yang dari padanya kita hidup pada saat ini: kita berada dalam kebaktian Advent atau Pentakosta atau Trinitas. ${ }^{34}$

Senada dengan Leew, Brink juga menegaskan, sebagaimana dikutip Abineno, bahwa introitus itu dapat disesuaikan dengan tahun gerejani atau khotbah dari minggu itu. Selanjutnya pujian sambutan itu sebaiknya diselaraskan dengan tahun gereja, khotbah dan liturgia. Sebisa mungkin introitus itu juga berasal dari Mazmur. ${ }^{35}$ Votum, Salam dari Kristus dan Introitus disambut dengan pujian yang megah dari jemaat, di mana pujian ini menggambarkan sukacita bahwa Allah ada di tengahtengah umat, dan orang percaya mengakui Allah sebagai yang maha kuasa, penuh dengan kemurahan, kasih dan penjaga serta pemelihara orang percaya.

\footnotetext{
34 Abineno, Unsur-Unsur Liturgia, p.11.

35 Ibid., p.12.
} 
Baik Votum, salam, dan panggilan ibadah (introitus) menegaskan bahwa ibadah itu adalah undangan Allah untuk beribadah, atau suatu pengumuman mengenai kehadiran Allah yang aktif dalam kehidupan. Salam dan panggilan ibadah ini memberikan penekanan teologis bahwa Allah itu selalu datang kepada umat-Nya sebelum umat datang kepada Allah. Allah selalu menyapa umat-Nya terlebih dahulu, sebelum manusia menyapa Dia. Karena itu, lazimnya votum dan salam itu bersifat Trinitarian untuk menegaskan bahwa umat menyembah Allah Tritunggal melalui karya Allah Tritunggal juga. ${ }^{36}$ Respon utama dari umat dalam pembukaan ibadah adalah pujian dan penyembahan, secara khusus pujian tersebut bersifat Trinitarian, yang mengajak umat memuji keindahan dan kemuliaan Allah, yang mana Dia adalah kudus, kasih, dan yang mau bersekutu dengan umat-Nya.

Ibadah dalam komunitas orang percaya menuntut kepada pengakuan akan kesalahan kita bersama karena telah merusak komunitas umat beriman dalam pelanggaran kita kepada Allah dan sesama. Bill Dyrness menulis pentingnya pengakuan dosa dalam ibadah demikian,

Worship does not come naturally to us, fundamentally because we are sinners. All of our relationships — with God, with each other, and with creation - are damaged. Shalom, God's original intent for each of us, has been destroyed. The meaning of the confession of sin and the assurance of pardon is very profound: it is the place in worship where shalom between God and people is restored. Christ has reconciled the believer to God and opened the way for us to worship 'in spirit and in truth' (John 4:24). ${ }^{37}$

Jadi, pengakuan dosa ini merupakan jalan pembuka penting untuk dapat beribadah di dalam roh dan kebenaran, dan karena itu, pengakuan

\footnotetext{
36 John D. Witvliet, “The Opening Worship: Trinity," in Leanne Van Dyk, ed. A More Profound Alleluia: Theology and Worship in Harmony, p.11,12.

37 William A. Dyrness, 'Confession and Assurance, Sin and Grace' in Leanne Van Dyk, ed. A More Profound Alleluia: Theology and Worship in Harmony, pp.31-54, 32.
} 
ini menjadi jalan pembuka kepada suatu ibadah sejati di hadapan Allah, dan juga jalan pembuka bagi partisipasi orang percaya terhadap misi Allah dalam dunia. Perdamaian dalam Kristus harus terjadi, dan pertobatan menuntun kepada rekonsiliasi, serta rekonsiliasi dengan sesama adalah suatu tanda bahwa hidup gereja tidak berpusat pada dirinya, melainkan sekarang berpusat kepada Kristus. Jadi, pengakuan dosa, pertobatan dan rekonsiliasi membentuk kembali jati diri gereja, yang adalah tubuh Kristus di dalam dunia.

Ibadah adalah pengakuan akan kemuliaan Allah yang tertinggi, dan di hadapan Allah yang Maha Tinggi dan suci, umat menyadari keberdosaan mereka, dan doa pengakuan dosa bertujuan untuk mengakui keberdosaan yang telah dilakukan oleh orang percaya. Doa bersama mengungkapkan bahwa dosa bukan hanya bersifat individu tapi juga bersifat menyeluruh dalam diri manusia. Karena itu, dalam doa ini mengarahkan orang percaya, bahwa kepenuhan hidup mereka yang sejati bukan pada diri mereka melainkan hanya ada di dalam Kristus dan direalisasikan dalam persekutuan dengan orang percaya dan dengan sesamanya. ${ }^{38}$

Selanjutnya, pembacaan berita anugerah yang menegaskan kepada umat bahwa Kristus yang mengampuni dan karena pelayan adalah mulut Allah maka berita pengampunan memiliki bobot otoritas Allah berdasarkan Kitab Suci. Dasar dari berita anugerah diambil dari ayat Kitab Suci. Pembacaan hukum/petunjuk hidup baru melanjuti berita anugerah untuk mengarahkan umat hidup berpusat kepada Kristus, dengan mentaati kebenaran-Nya. Respon umat dengan mengucapkan syukur kepada Allah terhadap firman pengampunan menegaskan bukan hanya sekedar mendengar isi berita tersebut, tetapi juga menegaskan wibawa dari firman Allah atas hidup orang percaya, dan umat dengan rela mentaati Kristus, mengkomitkan hidup kepada-Nya dan berserah kepadaNya.

Aktivitas pengakuan dan absolusi menjadi suatu paradigma dalam hidup bagaimana sebenarnya orang percaya berhadapan dengan konflik, kekecewaan, dan keterlukaan yang merayap masuk dalam hidup orang

38 Price, Liturgy for Living, p.55. 
percaya di dalam relasi mereka sebagai ciptaan yang telah jatuh. Melalui liturgi ini, umat diajar untuk mempraktekkan pengakuan, pengampunan dan rekonsiliasi, agar umat dapat bertumbuh dalam kepekaan akan jalan Allah dalam kehidupan dan umat menjadi waspada dalam kehidupan mereka secara personal dan komunal. Praktek umum yang juga dilakukan adalah memberikan salam damai kepada sesama, yang menegaskan untuk melatih umat sebagai suatu komunitas beriman.

Karena ibadah adalah perjumpaan dan persekutuan Allah dengan umat-Nya, maka ibadah tidak dapat dipisahkan dengan perhatian umat kepada Firman Allah, yang dinyatakan dalam Kitab Suci. Suatu sumbangan besar dari para Reformator dalam liturgi adalah dipulihkannya kembali doa iluminasi sebelum mendengar firman Allah. Doa iluminasi ini menegaskan pemahaman gereja bahwa Roh yang sama menginspirasi Firman dibutuhkan juga karya-Nya dalam hati para pengkhotbah agar mereka memiliki pemahaman yang sejati akan kebenaran firman Allah dan firman itu dapat berkarya dengan leluasa dalam hati umat Allah, ${ }^{39}$ sehingga dengan Roh yang berkarya dalam hati melalui dan dengan firman, jemaat sungguh-sunguh menyadari dosa mereka dan bersukacita akan keselamatan dari Allah. ${ }^{40}$

Pembacaan Kitab Suci dilakukan dan jemaat memberikan respon terhadap pembacaan Kitab Suci dengan menyebutkan, "Syukur kepada Allah," Selanjutnya, khotbah disampaikan dan dalam hal ini, Khotbah memiliki tiga aspek, yaitu kisah masa lalu tentang karya Allah bagi umatNya, yang mencapai puncak-Nya dalam Kristus, respon orang percaya terhadap kisah itu, yaitu bagaimana mereka menjadi setia dan apa yang akan mereka lakukan terhadap kisah itu dan percakapan kisah itu dalam pengalaman hidup orang percaya. Dengan kata lain, khotbah itu mencakup, "the story, dialogical engagement, [and] ethical exhortation." 41

\footnotetext{
39 Chapell, Christ Centered Worship, p.235.

40 Band. Pengakuan Iman Westminster 1.5 yang menegaskan tentang karya Roh Kudus yang berkarya melalui dan dengan firman Allah dalam batin orang percaya.

41 Price, Liturgy for Living, p.179.
} 
Setelah mendekati Allah dalam pujian dan pengakuan serta mendengarkan Firman, jemaat sekarang memberikan respons penegasan kepercayaan mereka kepada Allah melalui kredo rasuli atau pengakuan standar Reformed lainnya yang diakui. Liturgi memberikan ruang untuk respons ini sebagaimana anugerah Allah itu meminta umat-Nya mempersembahkan seluruh hidup mereka kepada Allah. Sejak abad kelima, pengakuan iman dimasukkan dalam liturgi ibadah, dan selanjutnya, Kaisar Karel Agung (742-814) yang menguasai sebagian besar wilayah Eropa Barat mewajibkan tiap orang percaya menghafalkan Pengakuan Iman Rasuli ini, dan pengakuan iman tersebut umumnya diucapkan bersama sesudah pembacaan firman/khotbah. Dalam era reformasi, letak pengakuan iman dalam ibadah mengalami perubahan karena para Reformator, khususnya Marthin Luther menyatakan bahwa pengakuan iman itu sebaiknya diucapkan sebelum khotbah. Di lain pihak, Zwingli setuju dengan Luther, namun juga dia bersikap elastis bahwa pengakuan iman itu dapat ditempatkan sebelum atau sesudah khotbah. Adapun Calvin dan Bucer menyatakan sebaiknya pengakuan iman ditempatkan sesudah khotbah dan doa syafaat, namun kemudian disesuaikan dengan pandangan Micron bahwa hal itu lebih baik sebelum doa syafaat. ${ }^{42}$

Alasan penempatan pengakuan iman sebelum khotbah adalah bahwa sekarang setelah umat menerima pengampunan Allah, mereka menyatakan pengakuan dihadapkan-Nya dan bersedia untuk melayani Dia. Namun secara umum, tradisi Reformed menerima posisi pengakuan iman itu sesudah khotbah, karena tujuan dari khotbah adalah membangun kepercayaan umat dan umat meresponi dengan pengakuan dan juga sebagai jawaban jemaat atas proklamasi Injil. Namun jikalau ditempatkan juga di depan sebelum khotbah, maka pengakuan iman juga berfungsi sebagai kesediaan jemaat untuk melakukan firman yang akan didengar. Jadi, posisi pengakuan iman itu entah sebelum atau sesudah khotbah, sama-sama memberikan makna dalam ibadah dan Abineno menyimpulkan mengenai urutan pengakuan iman baik di depan ataupun sesudah khotbah tetap keduanya berfungsi sebagai rangkuman dari injil

42 Abineno, Unsur-Unsur Liturgia, h.81 
yang akan dan yang dibacakan dan sebagai jawaban jemaat atas firman yang diberitakan. ${ }^{43}$

Chapell mengatakan bahwa pengakuan ini dapat diucapkan, atau dilantunkan secara bersama-sama mengikuti irama gereja kontemporer sebagai perwujudan dari kesinambungan gereja sepanjang abad dan solidaritas mereka dengan gereja di seluruh dunia. Pengakuan ini menegaskan bahwa gereja ada dalam kepercayaan yang historis, suatu penunjukan dukungan kepada mereka yang telah dianiaya karena iman, suatu sikap perendahan diri di hadapan kebenaran Kitab Suci, suatu kesaksian iman kepada sesama orang percaya dan dunia, pernyataan kesetiaan kepada Allah dan suatu upaya pembaharuan hati dan pikiran terhadap kebenaran yang atasnya kekekalan itu diletakkan bagi jiwa orang percaya. ${ }^{44}$

Liturgi mengalir kemudian menuju kepada persembahan dan doa syafaat, di mana persembahan adalah respon umat yang lahir dari kehendak yang rela untuk mempersembahkan diri kepada Allah. Persembahan uang, seperti persembahan korban yang diberikan dalam ibadah Israel, bukanlah suatu pembayaran karena kewajiban, namun persembahan adalah ekspresi dari fakta karena semua berkat dalam kehidupan adalah berasal dari Allah, maka semuanya itu harus dipakai dalam keselarasan dengan tujuan Allah. Tindakan berdiri kala persembahan dibawa ke depan altar adalah suatu cara untuk menegaskan bahwa keseluruhan dari siapa kita ini ada di dalam persembahan itu, yang dibawa dan didoakan dan dipersembahkan bagi pelayanan.

Doa syafaat yang dipanjatkan bukanlah sekedar meminta sesuatu dari Allah, melainkan melalui doa syafaat, kita dimampukan dengan anugerah-Nya untuk berpartisipasi dalam karya keimamatan Kristus, yang mempresentasikan segala sesuatu kepada Bapa. ${ }^{45}$ Sebagaimana

\footnotetext{
Abineno, Unsur-Unsur Liturgia, h.85.

Chapell, Christ Centered Worship, p.192.

5 Murray Rae, "The Liturgical Shape of Christian Life," Inaugural Lecture Knox Centre for Ministry and Leadership, 2008, dari http://knoxcentre.ac.nz/wp-
} 
Kristus sungguh merindukan agar umat manusia dapat kembali menemukan rumahnya di dalam Allah, maka demikian juga nampak dalam Doa syafaat Kristus suatu harapan rekonsiliasi bagi dunia, yaitu suatu rekonsiliasi yang tidak bersifat paksaan, melainkan menuntut suatu kerelaan dari penerimanya. Ketika orang percaya menaikkan syafaat, Roh Kudus menyatukan umat kepada tujuan Kristus, sehingga umat dimampukan untuk berbagi dalam karya syafaat-Nya, mengarahkan umat dalam bahasa kasih dan memberikan mereka tanggung jawab dalam tugas keimamatan ini.

Mengemban tanggung jawab kudus ini, Gereja bersekutu minggu demi minggu untuk tujuan ini, yaitu agar karya misi Kristus dinyatakan, sehingga manusia dapat kembali menyembah Allah yang benar dan menikmati persekutuan dengan Dia selamanya. Mengenai sasaran akhir dari misi yang adalah ibadah, Piper menegaskan,

Sasaran akhir dari gereja bukanlah misi, melainkan ibadah...Ibadah adalah sasaran akhir, bukan misi, karena tujuan akhir segala sesuatu adalah Allah, bukan manusia. Kalau zaman ini sudah berlalu, dan orang-orang tebusan yang tak terhitung banyaknya itu bertekuk lutut di hadapan tahta Allah, misi tidak akan ada lagi. Misi adalah kebutuhan sementara, tetapi ibadah akan ada selamanya. ${ }^{46}$

Kala umat berdoa bagi diri dan sesama, maka umat sedang mengekspresikan apa artinya memiliki relasi dengan Allah di dalam Kristus, yang mendamaikan dunia dengan diri-Nya berhadapan dengan kebutuhan khusus dan situasi tertentu. Karena itu, berdoa membawa kita kepada pengertian kepada diri kita sendiri, menolong kita melihat situasi yang kita doakan dengan benar dalam terang Kristus dan di dalam doa, umat mempersembahkan dirinya untuk menggenapi tujuan Allah dan menjadi sarana dari tindakan Allah dalam dunia.

content/uploads/2012/11/The-Liturgical-Shape-of-Christian-Life.pdf (diakses tanggal 13 Januari 2016).

46 John Piper, Jadikan Sekalian Bangsa Bersukacita! Supremasi Allah dalam Misi, (Bandung: LLB, 2001), h.7. 
Dalam prakteknya, ketika gereja membawa persembahan ke depan altar, secara umum gereja juga membawa elemen sakramen perjamuan kudus, yaitu roti dan anggur, sebagai pemberian representatif dari umat Allah yang sudah diampuni. Dengan meletakkan uang, dan elemen perjamuan itu di atas meja altar yang telah disediakan, umat juga mempersembahkan dirinya dan dunia, di mana uang merepresentasikan pekerjaan dari jemaat, dan mereka mempersembahkan apa yang menjadi bagian dari apa yang sudah mereka kerjakan dan sekaligus mempersembahkan dirinya seutuhnya kepada Allah. Demikian juga, dalam sakramen pengertian dan makna teologis dari sakramen perjamuan kudus mencakup pengertian yang lebih dalam lagi tentang apa artinya itu menjadi tubuh dan darah Kristus dan keterkaitannya dengan hidup orang percaya.

Roti dan anggur yang dipersembahkan memang secara simbolis berarti tubuh dan darah Kristus, namun dibalik tanda simbolis itu juga, ada suatu makna unik dari tindakan umat baik secara privat maupun korporat untuk menegaskan bahwa mereka juga akan menjadi tubuh Kristus dalam dunia. Jemaat bersama mengakui bahwa apa yang mereka persembahkan kepada Allah, dalam pengertian tertentu, sebenarnya bukan milik mereka, melainkan milik Allah yang diberikan kepada mereka sebagai penatalayan dari dunia ciptaan Allah. Selanjutnya tindakan dari membawa elemen perjamuan itu di atas altar memperkenalkan cara yang sangat dramatis mengenai karya manusia dalam bidang agrikultural, industri (alat-alat untuk membuat roti dan anggur), dan sistem dari transportasi dan distribusi, di mana semua ini dibawa oleh umat kepada Allah sang pemilik segala sesuatu. Jadi, di depan altar jemaat bukan hanya mempersembahkan dirinya saja, namun juga mereka mempersembahkan dunia di mana dia hidup dan berkarya. ${ }^{47}$

Setelah perjamuan berakhir, ibadah menuju ke arah anti klimaks, di mana anti klimaks ini ditandai dengan umat memberikan syukur kepada Allah dalam pujian dan memohon pertolongan Allah untuk melayani-Nya di dalam dunia, dan kemudian pendeta memberikan berkat Allah bagi

47 Price, Liturgy for Living, p.198. 
umat. Sebagaimana dalam salam, demikian juga dalam berkat, pelayan memiliki hak istimewa berbicara atas nama Kristus dan memberikan berkat Kristus dalam nama Allah Tritunggal, agar jemaat dapat pergi untuk hidup secara penuh sebagai orang Kristen. Berkat yang diberikan secara tradisional dipahami sebagai suatu cara menandai suatu obyek atau pribadi untuk berpartisipasi dalam kehidupan ilahi. Berkat menjadi suatu panggilan mewujudkan kehidupan ilahi dalam dunia, mewujudkan tujuan Allah dalam dunia dan bukan untuk menjustifikasikan keinginan diri. Berkat Allah berarti keinginan umat diberkati dan dibuat selaras dengan tujuan dan kehendak Allah. Jadi berkat memasukkan kita ke dalam pola dan tujuan serta karakter Allah dalam hidup. ${ }^{48}$

Karena itu, ketika jemaat pergi, mereka pergi dengan harapan kebangkitan dan hidup yang akan datang serta janji dari kehadiran RohNya yang senantiasa menyertai. Misi dan pergi meninggalkan ibadah (mission and dismissal) berasal dari kata kerja bahasa Latin yang sama, yaitu mittere, yang berarti mengutus. Pengutusan adalah proses akhir dalam ibadah, di mana umat diutus masuk ke dalam dunia guna menjadi misionaris dan pelayan dari Injil Kristus, ${ }^{49}$ yang melakukan pekerjaan Allah dengan benar.

\section{IBADAH DAN PERILAKU KEHIDUPAN ORANG PERCAYA}

Ibadah Minggu yang ditindaki dengan alur liturgi di dalamnya tidak dapat tidak berkaitan erat dengan kehidupan, karena memang liturgi dan kehidupan itu saling berkaitan satu dengan yang lain. Artinya, liturgi itu sendiri pada dasarnya secara ekslusif ditujukan kepada cara orang Kristen menghidupi hidupnya, meskipun seringkali dipahami bahwa liturgi itu ditujukan kepada ibadah dan teks-teks dari doa-doa. Liturgi itu bukan hanya sekedar suatu susunan ibadah dan teks-teks doa, melainkan liturgi sejatinya adalah suatu pola perilaku kristiani yang memang demikianlah yang harus mereka tindaki di dalam dunia, yaitu suatu ketaatan kepada Yesus Kristus, sang teladan sejati. Karena itu, Gereja

\footnotetext{
48 David L. Stubbs, "Ending of Worship: Ethics," in Leanne Van Dyk, ed. A More Profound Alleluia: Theology and Worship in Harmony, p.150-152. 
seharusnya memperhatikan dengan serius semua unsur yang ada dalam liturgi, karena jika tidak demikian, maka Gereja sedang memisahkan dan memutuskan dirinya dengan rantai hubungan yang ada di antara ibadah dan kehidupan. Bahkan gereja juga memisahkan diri-Nya dari Injil sebagaimana Chapell berargumentasi, mengutip pendapat Rayburn, bahwa jikalau gereja setia pada Injil, maka gereja itu akan menggemakan liturgi gereja yang sudah ada dalam sejarah. ${ }^{50}$

Sebagaimana Piper sudah menegaskan di atas bahwa tujuan akhir dari gereja adalah ibadah dan bukan misi, dan ibadah di sini yang dimaksudkan olehnya adalah cara bagaimana orang percaya itu hidup. Menariknya, justru di dalam liturgi, orang percaya diajar dan dididik dan dimuridkan bahwa demikianlah dia harus hidup. Stubb menegaskan,

...Liturgy set before us paradigms of exemplary conduct and involves us in a symbolic world that shapes us deeply. These paradigms and this symbolic world can provide a kind of lens through which we view our lives and the world as a whole. ${ }^{51}$

Stubb juga menegaskan bahwa dalam liturgi, umat bukan hanya diberikan informasi, namun umat sedang dibentuk menjadi orang kristen di mana tindakan dan hidup dikaitkan dengan dunia, dikaitkan juga hati umat dengan hati Allah dan pikiran umat dengan kebenaran Allah. Liturgi itu sesungguhnya adalah "the embodiment of the patterns of the kingdom of God in summary fashion." Karena itu, liturgi dapat disebutkan sebagai "a window of the kingdom," di mana kerajaan Allah itu menjadi tujuan dari hidup umat. ${ }^{52}$ Dalam hal inilah liturgi dan etika hidup orang percaya bersentuhan.

Liturgi dalam ibadah Minggu memiliki dua makna, yaitu dalam pengertian intensif, untuk menggambarkan apa yang terjadi kala orang percaya berkumpul untuk bersekutu menyembah Allah, dan liturgi dalam pengertian ekstensif, untuk menggambarkan apa yang terjadi kala orang

\footnotetext{
50 Chapell, Christ Centered Worship, p.25

51 Stubbs, "Ending of Worship: Ethics," in Leanne Van Dyk, ed. A More Profound Alleluia: Theology and Worship in Harmony, p.144.

52 Ibid., p.137.
} 
percaya meninggalkan persekutuan pasca ibadah untuk menjalani hidup mereka dalam dunia berhadapan dengan persoalan-persoalan kehidupan. Kedua pengertian ini saling bergantungan dan terkait satu dengan yang lain. Dalam liturgi intensif, gereja berjumpa dengan Kristus melalui Firman dan Sakramen, dan dalam perjumpaan ini, orang percaya diberikan daya dan kuasa dari Kristus yang tersedia untuk hidupnya dengan satu tujuan untuk masuk dalam karya di dalam dunia. Pada akhirnya, Liturgi ekstensif akan mengarahkan orang percaya untuk hidup sesuai dengan teladan dari Kristus dengan kuasa dan anugerah Allah yang tersedia bagi mereka.

Guna menolong gereja memahami arti dari fungsi sistolik-diastolik dari liturgi yang digunakan oleh Wolterstorff, maka ada istilah lain yang dapat digunakan, yaitu fungsi liturgi dalam pengertian intensif dan ekstensif. Korelasi di antara keduanya adalah liturgi intensif menarik umat keluar ke dalam dunia untuk melakukan liturgi ekstensifnya, dan demikian jugalah liturgi ekstensif itu membawa umat kembali minggu demi minggu ke dalam persekutuan kristiani, untuk mencari hadirat Allah dalam perwujudan Firman dan Sakramen, ${ }^{53}$ dengan suatu kesadaran bahwa dengan kekuatan diri semata, orang percaya tidak dapat menghidupi teladan Kristus di dalam dunia. Dalam hal ini, umat datang beribadah untuk menegaskan bahwa mereka sebenarnya membutuhkan suatu sumber kekuatan rohani yang tidak pernah gagal, dan sumber ini hanya dapat ditemukan di dalam Allah saja. Karena itu sekalipun mereka bertemu dengan kekecewaan, dan kegagalan dalam kehidupan, mereka akan tetap dapat bertahan berhadapan dengan semua itu secara benar. Liturgi ekstensif kita bukan hanya kisah kegagalan, namun juga kisah keberhasilan dan kemenangan, dan karena itu umat kembali dalam liturgi intensif untuk mempersembahkan syukur kepada Allah dalam pujian sukacita dan penyembahan.

Orang percaya terdiri dari individu yang terpisah, namun indentitas individu mereka menjadi nampak justru bukan dalam isolasi dari relasi mereka dengan individu yang lain, melainkan justru karena relasi tersebut ada dengan individu yang lain. Ketika orang percaya ditebus dalam

53 Price, Liturgy for Living, p.296-97. 
Kristus, orang percaya tidak dapat dipisahkan dengan persekutuan mereka, sebagai bagian dari anggota tubuh Kristus dengan saudara seiman yang lain. Karena itu, ketika umat menghidupi liturginya, baik secara intensif maupun ekstensif, umat melakukannya bukan hanya sebagai seorang individu belaka, tetap juga sebagai anggota tubuh Kristus, dan partisipasi umat dalam jemaat justru memperdalam juga identitas diri mereka, dan juga kehidupan individu itu yang sudah diperdalam, ditebus dan diampuni dalam Kristus diberikan kuasa oleh Allah bersama-sama untuk membentuk gereja, agen dari kehendak Allah dalam dunia. Jadi, orang percaya menyembah Allah bukan hanya sebagai tubuh yang privat, namun juga sekaligus sebagai tubuh korporat, karena kedua dimensi ini merupakan unsur mendasar bagi ibadah Kristen yang sejati.

\section{DAFTAR RUJUKAN}

Abba, Raymond. Principles of Christian Worship. London: Oxford University Press, 1957.

Abineno, J.L. Ch. Unsur-Unsur Liturgia yang Dipakai oleh Gerejagereja di Indonesia. Jakarta: BPK Gunung Mulia, 2005.

Chapell, Bryan. Christ Centered Worship: Kiranya Injil Membentuk Perbuatan Kita. Malang: Literatur SAAT, 2009.

Dyrness, William A. 'Confession and Assurance, Sin and Grace' in Leanne Van Dyk, ed. A More Profound Alleluia: Theology and Worship in Harmony. Grand Rapids, William B. Eerdmans Publishing, 2005.

Erickson, Craig Douglas. Participating in Worship: History, Theory, and Practice. Louisville: Westminster/ John Knox Press, 1989.

Flannery, Austin. The Basic Sixteen Documents Vatican Council II: Constitutions, Decrees, Declarations, Revised Edition. Northport, 
New York: Costello Publishing Company and Dublin, Ireland: Dominican Publications, 1996.

Jungmann, J.A. Pastoral Liturgy. New York: Herder and Herder, 1962.

Kendrick, Graham. Learning to Worship as a Way of Life. Minneapolis: Bethany House Pub, 1984.

Martin, Ralph P. Worship in the Early Church. Grand Rapids, Mi: Eerdmans, 1964.

McNeill, John T,Ed. Calvin: Institutes of the Christian Religion I. Philadelphia, the Westminster Press, 1960.

Moltmann, Jürgen. The Crucified God: The Cross of Christ as the Foundation and Critisism of Christian Theology. Minneapolis: Fortress Press, 1993. , Pengakuan Iman Westminster,1647.

Piper, John. Jadikan Sekalian bangsa Bersukacita! Supremasi Allah dalam Misi. Bandung: LLB, 2001.

Price, Charles P. and Weil, Louis. Liturgy for Living. New York: The Seabury Press, 1979.

Rice, Howard L. \& Huffstutler, James C. Reformed Worship. Louisville, Ky: Geneva Press, 2001.

Riemer, G. Cermin Injil: Ilmu Liturgika. Jakarta: Yayasan Komunikasi Bina Kasih/OMF, 1995.

Ryken, Philip Graham, Thomas Derek W.H. and Duncan III, J Ligon ed. Give Praise to God: A Vision for Reforming Worship. Phillipsburg: P \& R Pub, 2003. 
Schmemann, Alexander. For the Life of the World. New York: Athens Printing Company, 1973.

Stubbs, David L. "Ending of Worship: Ethics," in Leanne Van Dyk, ed. A More Profound Alleluia: Theology and Worship in Harmony. Grand Rapids, William B. Eerdmans Publishing, 2005.

Thompson, Bard. Liturgies of the Western Church. Philadelphia: Fortress Press, 1961.

White, James F. Pengantar Ibadah Kristen. Jakarta: BPK Gunung Mulia, 1980.

White, James F. Protestant Worship: Traditions in Transition. Louisville, Ky: Westminster John Knox Press, 1989.

Witvliet, John D. "The Opening Worship: Trinity," in Leanne Van Dyk, ed. A More Profound Alleluia: Theology and Worship in Harmony. Grand Rapids, William B. Eerdmans Publishing, 2005.

Witvliet, John D. Worship Seeking Understanding. Grand Rapids: Baker Books, 2003.

Wolterstorff, Nicholas. Hearing the Call: Liturgy, Justice, Church and World. Grand Rapids: Eerdmans, 2011.

Worship Study Committee, Authentic Worship in A Changing Culture. Grand Rapids, MI: CRC Publications, 1997.

\section{SUMBER INTERNET}

Murray Rae, "The Liturgical Shape of Christian Life," Inaugural Lecture Knox Centre for Ministry and Leadership, 2008, dari http://knoxcentre.ac.nz/wpcontent/uploads/2012/11/The-Liturgical-Shape-of-Christian-Life.pdf (diakses tanggal 13 Januari 2016). 